This is the author's version of a work that was submitted to / accepted for publication. Citation for final published version:

King, K. and Hemming, P. J. 2012. Exploring multiple religious identities through mixed qualitative methods. Fieldwork In Religion 7(1), pp. 29-47. doi: 10.1558/fiel.v7i1.29

\title{
Exploring Multiple Religious Identities through Mixed Qualitative Methods
}

\author{
Katherine King and Peter J. Hemming
}

Katherine King is a Lecturer in Leisure Studies in the School of Tourism at Bournemouth University. Her research interests include youth identities and lifestyles, the geographies of sport and leisure, and innovative qualitative methods. Bournemouth University, School of Tourism, Dorset House, Talbot Campus, Fern Barrow, Poole BH12 5BB, UK, kat.king@live.co.uk

Peter J. Hemming is Lecturer in Sociology of Education at Cardiff University. His research interests include religion and spirituality, education spaces, childhood and youth, emotions, identity, citizenship, community and mixed-method approaches. Cardiff University School of Social Sciences, Glamorgan Building, King Edward VII Avenue, Cardiff CF10 3WT, UK, HemmingPJ@cardiff.ac.uk

\begin{abstract}
This article offers a reflexive account of the process of researching religious identity with young people, and considers how combining methods may enable young people to explore their own identities in different ways. Drawing upon three participant case studies it explores the public-private spectrum produced as part of discussion groups, semi-structured interviews and an innovative online e-Journal research activity. As participants moved through each stage of the research process, the way in which they represented their religious identities shifted as they encountered differing social environments, became more practised at telling their own lives, or had evolved their own perspectives over time. Employing mixed methods contributes a more nuanced understanding of the role of religion in young people's lives yet also raises important ethical implications surrounding participant confidentiality in research.
\end{abstract}

Keywords: identity; mixed methods; qualitative methods; religion; youth. 


\section{Introduction}

Innovative qualitative research methods have become a favourable addition to the toolbox of techniques for exploring the complexities of young people's religious identities. The absence of an adequate existing "model" for investigating religious identity identified by Day (2009) has seen a particular emphasis on the combining of innovative techniques with more conventional methods of research (e.g. Coles, 1990; Erricker, et al. 1997; Nesbitt and Arweck, 2010). Mixed methodologies which encourage the generation of data in innovative and imaginative ways may be particularly successful for unearthing the multifaceted meanings surrounding young people's religious identity (King, 2013).

Qualitative studies of religious identity, more generally, stress the importance of a researcher's commitment to transparency and reflexivity in research, recognition of the coconstruction of knowledge, and consideration of the ways in which the research process can impact on participants in the field (e.g. Hopkins, 2009; Olson, 2009; Nesbitt and Arweck, 2010). This article offers a reflexive account of the process of researching religious identity with young people, and considers how combining methods may enable young people to explore their own identities in different ways. Drawing upon three participant case studies it explores the public-private spectrum produced as part of discussion groups, semistructured interviews and an innovative online e-Journal research activity, revealing the complex ways in which different religious identity positions emerged throughout the fieldwork.

\section{Researching Identity through Qualitative Methods}

Qualitative research is an intersubjective process with both "researcher" and "researched" producing socially constructed truths. As Schutz and Luckmann (1974: 6) argue, "we act and operate not only within the life-world but also upon it" and as researchers we are party to the fabrication of meaning. Knowledge is partial, forged and constructed through the research process, and continuously shaped by the politics of social interaction and by the tools we choose to capture and interpret phenomena. Qualitative research is concerned with explaining the meaning of "multiple truths" and the way in which they relate to the 
multidimensional contexts of social life (Mason, 2006). Consequently, the scientific apparatus which forms the connection between researcher and researched is similarly deemed worthy of inquiry in its own right (Aarsand and Forsberg, 2010).

Imbued by concepts of time, space and relationality, social life acts to com-plicate the process of identity formation requiring different presentations of the self in response to these changing subjectivities. Social identities are formed through an iterative, reflexive process through which the self is conceptualized as fluid and "unfixed" (Bauman, 2005). As individuals, the stories we tell about ourselves provide us with our own frames of reference which allow us to locate ourselves in an albeit contingent world (Somers, 1994; Leyshon and Bull, 2011). The construction of identity is therefore understood as an "active process of taking certain subject positions in an ongoing process of becoming - rather than merely being - in the world" (Jackson, 2004: 674).

Theorists have considered how young people's identities are informed through the interrelationship between their histories, cultural experiences and back-grounds as well as through social and power relations and discourse (Hall and Du Gay, 1996; McGinnis et al., 2007). Yet there is also the recognition of young people's own agency, as active producers who are equipped to make choices about their own identities and lifestyles (Valentine, 2000; Leyshon and Bull, 2011; Panelli, 2002). In keeping with these debates, I have argued that the construction of young people's religious identity should also be understood as a coconstitutive process which takes account of the myriad contexts and social spaces through which religious identity is shaped (King, in press).

As young people move between different contexts, the fluid nature of youth identities complicates the task of forming and maintaining a coherent core identity. For example, negotiating between the public and private spheres of life presents a challenge for young people who are both empowered, but simultaneously challenged by the range of responses and different codes of expression required as a result of increased opportunity and access to new spaces (Chaney, 1996). Indeed the assumption that social relations and practices can be easily located within one sphere or another ignores the complex combinations and connections between public and private which occur in everyday life (Gal, 2002). 
The way in which identity is influenced by context and relationships is in part in keeping with Kincheloe and McLaren's (2005: 320) argument that "as parts of complex systems and intricate processes, objects of inquiry are far too mercurial to be viewed by a single way of seeing or as a snapshot of a particular phenomenon at a specific moment in time." Young people construct their narratives of the self by continually adapting and reshaping their expressions of identity. Mixing qualitative methods utilizes a range of techniques in combination, in an attempt to expand the capacity for social explanation. They are particularly useful in youth-centred approaches to research because they allow participants to express their "selves" in a variety of ways. Different types of methods are likely to elicit different aspects of religious identity as co-constructed. Young people may articulate their views and opinions in different ways in different settings according to the perceived or intended audience. In this case, religious identity is also constructed to some degree by the research process, either through deliberate or resultant identity performances. Importantly, as Monahan and Fisher (2010: 362) remind us, "the responses of communities to researchers are important data in and of themselves."

This article examines the different processes involved in conveying religious identity across a range of methodological contexts and, in doing so, the way in which the boundaries between public and private may be constructed as part of research. As identity positions are constantly reproduced through social practice, and research is a part of not apart from the social world, the performances participants stage within the research settings warrant a more critical reflection on the differing roles research activities may play in the expression and formation of young people's religious identity.

\section{Outline of Youth on Religion Project Aims and Methods}

The Youth on Religion project was established to augment our contemporary knowledge of the role of religion for young people growing up in British multi-faith contexts. In brief, the research questions sought to address a number of key concerns relating to young people's construction and negotiation of religious identity, their attitudes towards religion and social cohesion in society, and the impact of religion in everyday lives. 
Research data were collected from three locations in England: the London Boroughs of Hillingdon and Newham, and in Bradford. These data comprised some 10,500 responses to a quantitative survey from 13 to 18 year-old pupils in secondary schools or colleges as well as qualitative research with around 158 young people drawn from these same schools/colleges. This article will focus on the qualitative dimension of the study drawing upon a subsection of the research conducted within the London Borough of Hillingdon.

The research adopted a creative approach to research design encouraging young people to express themselves in different ways by inviting them to participate in an assemblage of three different methods. Forty young people aged between 16 and 17 years from seven different schools in Hillingdon took part in a series of discussion groups, e-Journal activities and paired interviews over a six-month period (see Table 1). Young people identified themselves by means of a range of faith and non-faith positions including Christian, Sikh, Hindu, Jain, Muslim and no religion.

\begin{tabular}{|l|l|l|l|}
\hline & Summer Term & Summer Break & Autumn Term \\
\hline Discussion group & & & \\
\hline e-Journal & & & \\
\hline $\begin{array}{l}\text { Semi-structured } \\
\text { interview }\end{array}$ & & & \\
\hline
\end{tabular}

Table 1. Methods timeline.

Introduction to Discussion Groups and Paired Interviews

The research employed both discussion groups and semi-structured interviews with young people, thus optimizing the inherent differences in the data generation process, capturing a wide range of perspectives on several issues during the discussion groups and adding depth 
through semi-structured interviews. The first method involved a discussion group held on the participants' school premises lasting 45 to 60 minutes with between four and seven young people and facilitated by two researchers. Discussion groups are what Marshall and Rossman (2011) refer to as "socially orientated" with the researcher encouraging discussion between participants within a supportive and collegial environment. The emphasis on social interaction meant this method was useful for developing a rapport with the participants early on in the research process and for introducing the participants to the broad issues of the research. Discussion groups were partly pre-existing, formed of young people in the same year group and attended by participants in friendship pairs, and therefore were likely to retain some relevance to the social context within which their ideas are formed and made (Kitzinger, 1994). The discussion groups usually comprised young people who identified as a range of faith and non-faith positions acting as a useful forum for observing the way in which young people interact in discussing often sensitive issues with others who may have different perspectives.

The discussion groups used a variety of different formats to initiate and facilitate discussion about one or two of the following themes: religion in the area/community; positive and negative aspects of religion; and the role of religion in education and society. Activities included asking participants to draw maps of their areas to represent their individual everyday geographies and discuss how religion and culture are experienced in their area, presenting clippings from newspapers to discuss the role of religion in wider society, and using vignettes about fictional scenarios to explore young people's opinions on the role of religion in education and schools. Throughout the discussions, young people were encouraged to draw upon their own experiences to illustrate their opinions.

In addition, all participants were invited to take part in face-to-face semi-structured interviews in friendship pairs although two young people participated in individual interviews where they were unable to find a partner but still expressed an interest in taking part. Interviewers used a list of ten standard questions which included a series of prompts if young people found it difficult to think of something to say. 
Principally, paired interviews were important for addressing positionality and balancing power in research with young people, but similar to the discussion groups, sought to maintain the social dynamic of the youth experience as much as possible. Thus, as Burgess et al. (1988: 310) have contended, "the importance of small group interviews is that they enable individuals to share in a discussion within a social setting which in many ways mirrors those outside the group." In comparison to the discussion group, however, the interview topics were focused on the personal experience of religion and covered issues such as religion and personal identity, religion in the family, and experiencing religion with friends. It was envisaged that the intimacy of the interview situation might encourage respondents to be more open in their responses than in discussion groups (Kvale, 1996; also see Hopkins, 2009) and therefore young people were encouraged to talk about their own perceptions and understandings through personal examples or shared experiences of certain events.

\section{Introduction to the e-Journal}

Originally conceived as a medium for documenting religious observances, and more recently as sites of "self-exploration, self-expression and self-construction" (O'Sullivan, 2005: 60), diaries have long been recognized as important platforms for various forms of analysis within social and cultural research. Children and teen-agers constitute one of the fastest growing internet populations of any generation (McKay et al., 2005) and online journals provide an important medium for young people to explore and exhibit their identities and form personal and social net-works in a space that is available for personal ownership and control (Hodkinson and Lincoln, 2008).

e-Journals were employed within this research for two reasons. First, because they allowed the researcher to understand young people's lives from their own perspectives as a more private and personal reflection than was possible in the case of paired interviews or discussion groups reflecting the tenets of youth-centred and participatory approaches to research (also see Moinian, 2006; Worth, 2009). Second, e-Journals offered an opportunity to capture the everyday meaning of religion in young people's lives and continue data collection beyond the school gates. Online forms of journalling have become embedded in young people's individual lives as a means to document personal events or emotions 
(Hodkinson and Lincoln, 2008) and therefore e-Journals retained a relevance to young people's lifestyles, complementing the use of other school-based, and more conventional, methods of research.

Young people were invited to complete an e-Journal to document their thoughts, beliefs and experiences of religion over a six-week period during the school summer break. The eJournal activity was introduced to young people at the initial group discussion session where all participants were given guidance notes and invited to sign up for an e-Journal account. Hookaway (2008) distinguishes between two forms of online diaries administered as part of research: unsolicited diaries which are spontaneously maintained by participants, and solicited diaries which are researcher driven. This research adopted a solicited approach whereby the researchers suggested different themes for young people to write about and included examples of diary entries for ideas and guidance. Young people were asked to write about four topics over a six-week period, with a change in topic appearing every two weeks (see Table 2). Suggestions were included in the guidance notes and were also posted online, appearing as part of their individual e-Journal threads. The guides were intended as useful starting points to give the activity structure and purpose for those less familiar with diary writing. However, young people were encouraged to write freely on the role of religion in their lives if they so wished.

\begin{tabular}{|l|l|l|l|l|l|}
\hline $\begin{array}{l}\text { Week } \\
\text { beginning } \\
\text { 26th July }\end{array}$ & $\begin{array}{l}\text { Week } \\
\text { beginning } \\
\text { 2nd August }\end{array}$ & $\begin{array}{l}\text { Week } \\
\text { beginning } \\
\text { 9th August }\end{array}$ & $\begin{array}{l}\text { Week } \\
\text { beginning } \\
\text { 16th August }\end{array}$ & $\begin{array}{l}\text { Week } \\
\text { beginning } \\
\text { 23rd August }\end{array}$ & $\begin{array}{l}\text { Week } \\
\text { beginning } \\
\text { 30th August }\end{array}$ \\
\hline $\begin{array}{l}\text { Religion and } \\
\text { my family }\end{array}$ & $\rightarrow$ & $\begin{array}{l}\text { Religion in my } \\
\text { area }\end{array}$ & $\rightarrow$ & $\begin{array}{l}\text { Religion and } \\
\text { society }\end{array}$ & $\rightarrow$ \\
\hline $\begin{array}{l}\text { Me and } \\
\text { Religion }\end{array}$ & $\rightarrow$ & $\begin{array}{l}\text { Me and } \\
\text { Religion }\end{array}$ & $\rightarrow$ & $\begin{array}{l}\text { Me and } \\
\text { Religion }\end{array}$ & $\rightarrow$ \\
\hline
\end{tabular}

Table 2. Timetable of e-Journal topics. 
The e-Journal aimed to offer individuals increased control, flexibility and interpretation over the production of knowledge than may have been available as part of the other methods. Participation in the e-Journal activity was optional, and it was completed independently, in young people's own time. Consequently, 14 young people chose to complete the activity. Participants were able to complete as many diary entries as they wished: for example, some wrote one new entry for each topic whereas others wrote more or less frequently and more sporadically. The e-Journal was able to reach beyond the context of traditional research techniques as participants could also choose when and where to complete their entries with many submitting entries late at night or while on holiday. The e-Journal revealed a variety of writing styles. Some participants, for example, used the e-Journal as a personal space to pose rhetorical questions or ponder particular issues, while others used the diaries as a reallife account of their activities, documenting holidays or occasions and relating this to their ideas about religion.

The most useful feature of the e-Journal was that diary entries could be edited, revisited or deleted at any time giving participants the opportunity to consider their responses and exercise more control over what they intended to say. While the e-Journals contained mostly written text, users were able to upload pictures, scanned newspaper clippings, videos, maps and audio clips to accompany their journal entries. The written text could also be animated with "emoticons" such as smiley faces, and font style and colour could be changed.

Traditionally, paper diaries are solitary reflections intended to be hidden from public life yet were often written for an imagined readership (O'Sullivan, 2005; Moinian, 2006) whereas new forms of online diarying such as status updates, blogs and tweets are much more interactive. While the e-Journals were completed online, individual accounts were secure and could be edited only by the participant, and viewed by the research team. In this way the e-Journal shares more similarities with a paper diary than a blog in terms of its status as a semi-private space. 


\section{Religious Identity and Mixed Methods}

The remainder of the article draws upon examples from three participant case studies to explore the way in which respondents present their own identities through the different methods employed as part of the research process. The first participant is Charlotte, a 17year-old white, British female who describes herself as a Protestant Baptist. Saneha is a 17year-old female who describes her nationality as British, her ethnicity as Indian and her religion as Sikh. The third participant, John, is a 17-year-old white, British male who identifies himself as having no religion.

\section{Performing Religious Identity}

Different research environments may be experienced as a combination of personal, private, public or community contexts which differently support the marking of individual or collective identities as individuals move between them. It is important, therefore, to acknowledge the different types of discourses that may be expressed in the interconnected arenas of public and private and the social processes and contexts which shape the resultant responses (Kitzinger, 1994). The first case study participant, Charlotte, demonstrates the spectrum of public to private produced through the employment of multiple methods as part of research.

The first method employed was a group discussion with six pupils aged $16-17$ years old and two researchers (see Table 1), representing a mixture of religious and non-religious identities. During the discussion group Charlotte spoke on only four separate occasions. When she spoke she contributed to discussions about different interpretations of religious rules within religious groups and separately about the tensions between religious groups which may result from teaching about terrorism in schools. Yet it was what was not said that was often most revealing about Charlotte's experience of discussing religion with her peers. During part of the discussion, some of the participants began talking about the negative aspects of religion and the way in which religion may be associated with violence. At this point one of the researchers noticed that Charlotte screwed up her face as though she did not agree with what the others were saying yet she did not contribute any 
alternative opinion and sat quietly for the rest of the discussion. These non-verbal clues hinted at some dissatisfaction with the negative positioning of religion by others in the room, yet it was only in the research activity which followed that Charlotte demonstrated the centrality of religion as part of her own life, contextualizing her views about the wider role of religion in society.

Subsequent to the group discussion session, Charlotte completed the second research activity, the e-Journal, submitting four lengthy entries over the summer break. Charlotte wrote extensively about the importance of her Christian faith often illustrating this with examples of her own lived experiences. She discussed the importance of prayer and communication with God as part of daily life and relayed a story about losing an article of personal significance which she felt God had helped her to find. In one particular entry Charlotte wrote about a significant spiritual experience which occurred while attending a Christian summer camp. She described attending a group seminar session, during which she was invited to receive the Holy Spirit.

She then told us to close our eyes and focusing on nothing just complete emptiness, which I now know is very dangerous as it allows all sorts of demons access to your mind as you are unprotected. Then she began to describe various feelings i.e. if your left arm feels numb then come over here as you are ordained to be a prophet. I know now that this would not be God's way of working either. On that occasion God stretched out his divine hands and protecting me from harm by causing me to faint and miss the rest of the session (having all been standing up with our eyes closed). Fainting under the power of the Holy Spirit in such occasion is not uncommon thus no one thought it strange that I fell to the ground. My glasses fell off and I do not know how long I was knocked out for lying on the ground - it can't have been much longer than 20 minutes max until the session ended and everyone left. Thus my friends found me and I was sent to the medical tent etc. The Lord protected me that day by causing me to faint. (Charlotte $23 / 8 / 2010$ at 6:17pm)

This very personal story documents a moment of vulnerability and of discomfort which the participant clearly found distressing yet felt able to disclose within the "confines" of the eJournal. In this particular example, the e-Journal acted in similar ways to that of a private diary: providing a place to document intimate experiences or significant events, and explore 
the personal meanings and emotions attached with these events. The online nature of the e-Journal and what others have termed the "facelessness of the net" (Nesbitt and Arweck, 2010: 12) may have further facilitated the discussion of potentially sensitive topics.

In another example, participants were prompted to discuss how religion is experienced as part of their family or among their friends, and Charlotte chose to talk about the difficulties finding common ground with friends at school because of the restrictions of her religion:

Partly, or should I say mostly, due to being a Christian I do not meet up with friends outside school I am more commonly found alone. I don't approve of going out and getting drunk which is what most parties of people our age are. I have decided myself that I will not drink alcohol unless I have to but then I don't like it anyway (or the types that I have tried). I don't swear and I don't like to constantly hear people swearing or taking the Lord's name in vain i.e. saying 'Jesus' or 'Oh God'. Furthermore the people that I have been friends with are into rock music and my Dad has taught me as based upon the Bible of the evil influences of that type of music and in fact much modern music. Rock music is particularly bad as it is so heavy and half the time you do not know what the people are saying. (Charlotte 23/8/2010 at $6: 17 \mathrm{pm})$

Marshall and Rossman (2011) have argued that some young people may be self-conscious or under-confident during semi-structured interviews, and for Charlotte it was clear that the e-Journal gave her more opportunity to express her opinions and feelings towards her experiences in forming and maintaining friendships at school than the other, by their nature, more public contexts. The visible presence of Charlotte's peers in the other contexts of the discussion groups and the paired interview would most certainly have hindered such an account.

Charlotte attended the final research activity of the paired interview with her project partner "Jacob," who identified himself as an atheist. During the interview, participants were invited to comment on how religion affected their daily life, for example, what they chose to eat, or wear, and also their attitudes to marriage and dating. When asked about her attitudes towards dating and marriage, Charlotte became noticeably uncomfortable and 
avoided answering the question because this was something she felt she had addressed through the e-Journal.

\author{
Charlotte: \\ Um yeah I think I wrote most of what...the answer to that in the e-Journal. Do you need it \\ said again? \\ Researcher: \\ Well um... I mean if you don't want to discuss it now you don't have to, but if you want to \\ just briefly kind of point me towards the points that you...? \\ Charlotte: \\ Um. \\ Researcher: \\ Or you don't have to. \\ Charlotte: \\ It took me a while to write it, I'm just trying to think now if I could summarize it.
}

While the participant was willing to discuss particular personal experiences as part of the eJournal method, her participation in both the group discussion and the paired interview formats appeared hindered. Kaun (2010) has described how participants may develop a feeling of anonymity in their use of online research methods, sometimes presenting a particular identity performance in one setting that they may not feel comfortable sharing in another. The increased distance between researcher and researched afforded by the online context of the e-Journal may have been partly responsible for this loss of inhibition; the "online mask" enabling participants to write more openly and honestly (Hookaway, 2008: 96). Simultaneously, however, the presence of her peer group in the other research settings seemed to contribute to a more guarded account. The opportunity to share individual accounts and experiences with others in a similar social position is a great advantage of discussion group and paired interview approaches, yet it has been argued that the groupbased element upon which this is based poses challenges for issues of confidentiality and anonymity as part of research (Bagnoli and Clark, 2010). The use of different types of methods in combination blurs the boundaries between participant perceptions of public and private space, resulting in complex ethical issues surrounding participant confidentiality. 
For the second participant, John, the private feel of the e-Journal method may also have facilitated a more frank disclosure of his opinions around religious difference and community cohesion than in the other face-to-face contexts. While these topics were not addressed in the discussion group context, while attending a paired interview with a female participant, John explained his views surrounding the portrayal of religion in the media.

John:

Well I know at the minute Muslims and their religious views are seen as really bad aren't they? Like especially over what's happening in Afghanistan and stuff. Cos you get... I know in the Sun I read about how you get these Muslim preachers preaching about killing the whites and that... British soldiers and that. So they're portrayed as bad, and some of them are bad, but then some of them are going to be nice aren't they?

In his e-Journal entries, the participant was more explicit about some of his views surrounding the treatment of Muslims within wider Western society.

I know that France have banned the burker [sic] or at least that's what I read in the paper a while back. This is a good idea as the burker hides the face of an individual and the identity of a person. They could say that they are someone that they aren't and no one can question this. This is bad, who knows who could be hiding behind it, Bin Laden could be for all we know, a terrorist or someone who could cause harm. It is dangerous. (John 2/9/2010 at 12:50pm)

In a second example, the participant discussed issues around community cohesion on a more local level and expressed some discontent towards the politics of entitlement operating for members of ethnic minority groups expressed, in a derogatory manner, some discontent.

I feel that the guests of the country are better off in society and I would say I have good reason to think that. They do have money and nice things and nice houses. This doesn't seem like a religious issue but I do think that religion can be used to define these groups. Also I 
would say that certain people use their religion to lever advantages and if this don't work people will be branded racists. (John 12/8/2010 at 6:00pm)

In this instance, the e-Journal acted as an un-judged place of transgression (Kaun, 2010), particularly in comparison to the school setting of the other methods where it may have been unacceptable to express these viewpoints given the power relations which shape research in institutional contexts (see Denscombe and Aubrook, 1992).

With no direct contact between interviewer and interviewee, Jenkins (2010) has argued visual anonymity may help to lessen inhibition and coyness and there may be less incentive for participants to adopt or maintain a public façade. It is the anonymity of the online context and the increased distance from the researcher which often facilitates less selfconscious accounts (Hookaway, 2008) yet it was clear that for Charlotte it was also the privacy of this form of communication that encouraged a more personal "storying" of her experiences, hiding her views from young people, whom she expressly disclosed, she did not consider her friends. In both cases, participants disclosed more about their private selves through the e-Journal method where the audience was less visible, and their accounts were not shared with other young people.

\section{Constituting Religious Identity through Research Practice}

The employment of research methods along a spectrum of public and private allowed young people to articulate their identities in different kinds of ways, but as research practices are embedded in and not distinct from the construction of social life so too the experience of taking part in these activities acts to affirm or consti-tute (religious) identity for young people. Pointing to the central role of research methods in the production of knowledge, Day (2009: 99) asserts, "what people tell us about what they believe will be determined largely by how we ask them," yet articulating a particular position on religion can be a difficult and complex task. In employing a mix of qualitative methods the matter of exploring young people's individual beliefs was reserved for the paired interview and the eJournal, when the setting was more "private" and participants were more familiar with the research environment (although undoubtedly expressions of personal beliefs sometimes 
emerged within a discussion group setting if young people chose to discuss them). What resulted from this layering of methods was the development of individual belief narratives as demonstrated by the extracts below.

Embedded in daily life, the personal spaces of online journals often act as central points for identity work (Kaun, 2010) within which young people are able to piece together their fragmented identity positions and develop these with some degree of consideration and coherence. The e-Journal provided a platform for young people to give a considered account of religion in their lives and for one participant, Saneha, a place to describe what it meant to her to be a Sikh.

I feel that I am in between not that religious and not that non-religious if $u$ know what I mean!! I pray but sometimes I feel bad that I am doing it in hard times and forget in the good times... I make routines and try to keep them but just can't... I do it because I feel at peace. I feel that an obstacle will vanish...also it makes me more active getting up in the morning early taking a shower...makes me feel fresh as well so I feel it disciplines me as well. (Saneha $18 / 8 / 2010$ at $6: 10 p m)$

In the extract above, Saneha reflects the difficulties she encounters in con-templating her own religiosity and consequently the uncertainty surrounding her own religious identity. The extract is punctuated with pauses as a visible reminder of the complexity of the issue of articulating a feeling of belief or a measure of religiosity. Saneha also attended a paired interview with her friend approximately six weeks after the e-Journal activity was completed, and while she was still formulating her response she discussed her Sikh identity at some length in this situation.

Saneha:

I think as a Sikh I believe in like worshipping, like I'm not really an agnostic. Like I don't think oh is there God or isn't there - I actually do believe there's God. It's just... I sometimes think that...other than just praying it's more about the deeds you do as well. Like if you're like a good human being. So I don't really like... I'm a Sikh, but I'm not really like... I'm not really...like the rules and everyone...like you have to pray like these many times a day and everything... I think it's just... to me I think all right fine, like you know, you want to pray - if 
you really want from the heart, you should pray. But then if you don't it doesn't mean that you're not a Sikh it's just...you just do good deeds and you sort of like respect the religion. And I think yeah, I think that's what...that's what Sikh means to me to be honest.

At the end of the interview, however, she commented to the researcher that the interview experience had made her reflect on her religion in a way she hadn't done so before, hinting at the performative processes at work in qualitative research (Monahan and Fisher, 2010).

Saneha:

This has actually got me thinking a bit more.

During interviews and group discussions several participants remarked it may have been the first time they had really considered why they held the views they did or certainly it was the first time they had verbally expressed their rationale for such a position. Through research practice, young people constructed their religious identity, altering, adapting and rehearsing these narratives through the sequence of research activities. As Warren and Fassett (2002) have argued, the act of repeating an identity works to constitute who we are and taking part in this research may have formed part of young people's wider negotiations of their religious identity.

As researchers, we are not excluded from the performative and constructive processes of research (Nesbitt, 1998) and our own positions may have shifted or cemented according to our various research experiences. Several authors have commented on the issues that can arise while conducting fieldwork on religion resulting from the presentation of their own religious identity positions during data collection (Schweber, 2007; Hopkins 2009; Olson, 2009). At the very least, the power relations that characterize the research encounter may become more evident in research which requires "the participant" to disclose their own religious positioning and the researcher to construct their own identity narrative.

On more than one occasion informants enquired about a researcher's own religious position, often assuming that because we were asking questions about religion, we ourselves must hold strong religious convictions. Two participants who identified as Hindu 
and Christian respectively enquired about the researcher's religious position at the end of a lengthy paired interview during which both participants had stressed the importance of religion in their own lives. In this instance the researcher identified her position as agnostic, but emphasized her Christian upbringing and openness to spirituality, not wanting to estrange the participants who had clearly assumed she followed a religion. On the whole, however, religious or non-religious self-identification on the behalf of the researcher did not appear to affect the dynamics of the research encounter, particularly as these questions were often posed after interviews had been completed (also see Olson, 2009).

For Charlotte, the e-Journal was also an avenue for locating and negotiating her religious identity, but in addition it was linked to her own religious practice. The act of diarying itself formed part of her everyday transactions with God, echoing historical accounts of spiritual journals used to self-document religiosity in the seventeenth century (see O'Sullivan, 2005).

Having been very busy with everything, journalling is something that I find important in my faith but do not always get time to do. Being the summer I spend more time with my family and have more time for my religious reflections. Of course I still read my Bible every day and do some kind of praying but the summer means I receive more time to do this in a longer relaxed way. (Charlotte 16/8/2010 at $11.16 \mathrm{pm}$ )

The process of journal writing was familiar to Charlotte, particularly in relation to her own spiritual explorations; nevertheless the e-Journal was intended for a researcher audience, as opposed to a private reflection and was researcher driven, rather than written according to participants' own priorities. In one particular entry she demonstrated an awareness of the researcher, reminding herself of the purpose of the e-Journal, in comparison to her spiritual diary writing, consequently altering her performance of the self (Martinson, 2003).

Well. This time I have decided that I need to stick more to the agenda of what I am meant to write about rather than get carried away writing from one thing to the next like I do when I normally write in my journal/diary. (Charlotte $1 / 9 / 10$ at $4.32 \mathrm{pm}$ ) 
Kaun (2010) explains that in using diaries as part of social research, participants may choose to present their selves in particular ways or feel pressure to produce valuable content, aware that they are "under observation." The fact that the participant refers to what she is "meant to write" draws attention to the way in which solicited diaries may have certain implications for construction of meaning. Diaries that are created entirely for the purposes of research may lack the authenticity or truth of those which are completed through individual choice. Yet, as all truth is constructed and all performances are, in a sense, staged, these extracts are still important because they are deeply revealing of how individuals perceived them-selves and would like to be perceived (Monahan and Fisher, 2010). Perhaps what emerges as most significant is that the physical presence of an audience in the discussion groups, the familiarity of a paired interview with a friend, or the perceived privacy of the e-Journal all acted to produce these truths in different ways.

\section{Conclusion}

Employing a combination of methods can help us to capture the multidimensionality of social experience (Mason, 2006), in this case contributing to a more holistic picture of the role of religion in young people's lives and the way in which this informs their individual identities.

Reflective in nature, the e-Journal offered the most significant opportunity for personal ownership and control and in these cases proved an important avenue for exploration and exhibition of religious identity. It was through the online dimension of the e-Journal that accounts became more rooted in participants' local experiences and everyday lives (Aarsand, 2008), and for one participant, became part of spiritual practice. The electronic dimension of the e-Journal held important implications for the way in which accounts were maintained, managed and accessed (O'Sullivan, 2005). This technique allowed participants more space and time to consider, reflect and adapt their responses, and by appealing to young people's digital literacies, retained a contextual relevance to their own lives (see McGinnis et al., 2007 and Kaun, 2010). e-Journal methods can complement the use of school-based research methods by providing young people with the option of exploring 
their individual experiences, in their own time, elsewhere, where young people are less directed by those with authority.

Group discussions were also of a familiar nature for young people, mimicking the spatial and social context of the classroom as they were performed on school premises and were attended by peers from their school year group. For some this arrangement may have felt safe and familiar; for others it was a less comfortable environment to discuss particular views of religion. Group discussions were a useful forum for obtaining a collective opinion; however, at times, the classroom code of conduct may have permeated these encounters resulting in the censoring of topics which countered the school ethos or which the group may have identified as inappropriate. During paired interviews participants were often more at ease with the processes of research and had become practised at discussing their own views. Paired interviews were useful for exploring individual belief narratives in a face-toface context where, contrary to the e-Journal approach, researchers could interact with participants and explore their responses through discussion.

Privileging a sensitivity towards the ways in which young people may experience the process of researching religious identity has provided additional insight into the performance, presentation and lived experience of the process identity formation for young people. Each method successfully addressed particular issues and concerns independently, yet by applying a reflexive lens to the process of layering of methods by individual cases, the subtleties which shape young people's individual experiences have emerged. Mixed qualitative methods offered participants (and sometimes researchers) the opportunity to explore their religious positions in different ways, and consequently, religious identity was continually (re)constructed as part of participation in research.

As participants moved through each stage of the research process, the way in which they represented their religious identities shifted as they encountered differing social environments, became more practised at telling their own lives, or had evolved their own perspectives over time. The visible presence or absence of the researcher or participant peers was particularly illustrative of the way in public and private are differentially constructed by research participants at different times, with group discussion and paired 
interview data more likely to reflect common social discourses around religion in wider public life. For Monahan and Fisher (2010) the spectrum of public and private spaces produced through the layering of methods is revealing of how individuals perceive themselves and others, and how they would like to be perceived and portrayed as part of research. This does, however, raise some important considerations surrounding the construction of knowledge as part of research which draws upon a range of methods in combination, and the subsequent reporting of these multiple truths.

There are important ethical implications surrounding participant confidentiality in research which invites young people to document their experiences across a range of sites. These examples have shown how participants discuss certain aspects of their lives in one sphere that they may be unwilling to revisit in the next. Researchers must show sensitivity to the participant experience and an awareness of the subjectivities which characterize the different research settings. Some of these ethical complexities can be tackled through employing what Holt (2004: 13) terms "empowering research relations." Here, she has argued that the fluidity of role performance and identity positions during the research process represents a shifting of power relations, which, if harnessed, can be beneficial for the relationship between researcher and researched (Holt, 2004). Providing young people with opportunities to self-report as much as possible acknowledges their individual capabilities to censor their accounts for themselves. Examining how participants experience the processes of research further increases our understanding of the process of constructing religious identity and reflects calls for a more thoughtful consideration of the complex ethics of social religious research (see Olson, 2009).

\section{References}

Aarsand, P. A. 2008. "Frame Switches and Identity Performances: Alternating between Online and Offline," Text \& Talk, 28.1, 147-65. http://dx.doi.org/10.1515/TEXT.2008.007 
Aarsand, P. A., and L. Forsberg. 2010. “Producing Children's Corporeal Privacy: Ethnographic Video Recording as Material-Discursive Practice," Qualitative Research, 10.2, 249-68. http://dx.doi.org/10.1177/1468794109356744

Bagnoli, A., and A. Clark. 2010. “Focus Groups with Young People: A Participatory Approach to Research Planning," Journal of Youth Studies, 13.1, 101-19. http://dx.doi.org/10.1080/ 13676260903173504

Bauman, Z. 2005. “Identity for Identity's Sake is a Bit Dodgy," Soundings, 29.1, 12-20.

Burgess, J., M. Limb and C. M. Harrison. 1988. "Exploring Environmental Values through the Medium of Small Groups. Part One: Theory and Practice," Environment and Planning A, 20, 309-26. http://dx.doi.org/10.1068/a200309

Chaney, D. 1996. Lifestyles. London: Routledge.

Coles, R. 1990. The Spiritual Life of Children. Boston, MA: Houghton Mifflin.

Day, A. 2009. "Researching Belief without Asking Religious Questions," Fieldwork in Religion, $4.1,86-104$.

Denscombe, M., and L. Aubrook. 1992. "The Ethics of Questionnaire Research on Pupils in Schools: 'It's Just Another Piece of Schoolwork,'” British Educational Research Journal, 18.2, 113-31. http://dx.doi.org/10.1080/0141192920180202

Erricker, C., J. Erricker, C. Ota, D. Sullivan and M. Fletcher. 1997. The Education of the Whole Child. London: Cassell.

Gal, S. 2002. "A Semiotics of the Public/Private Distinction," Journal of Feminist Cultural Studies, 13.1, 77-94.

Hall, S., and P. Du Gay. 1996. Questions of Cultural Identity. London: Sage. 
Hodkinson, P., and S. Lincoln. 2008. “Online Journals as Virtual Bedrooms: Young People, Identity and Personal Space," Young, 16.1, 27-46. http://dx.doi.org/10.1177/ 110330880701600103

Holt, L. 2004. "The 'Voices' of Children: De-centering Empowering Research Relations," Children's Geographies, 2.1, 13-27. http://dx.doi.org/10.1080/1473328032000168732

Hookaway, N. 2008. “'Entering the Blogosphere': Some Strategies for Using Blogs in Social Research," Qualitative Research, 8.1, 91-113. http://dx.doi.org/10.1177/ 1468794107085298

Hopkins, P. E. 2009. “Women, Men, Positionalities and Emotion: Doing Feminist Geographies of Religion," ACME: AN International E-Journal for Critical Geographies, 8.1, 117.

Jackson, A. Y. 2004. "Performativity Identified," Qualitative Inquiry, 10.5, 673-90. http:// dx.doi.org/10.1177/1077800403257673

Jenkins, S. 2010. “New Technologies, New Territories: Using the Internet to Connect with Sex Workers and Sex Industry Organisers," in K. Hardy, S. Kingston and T. Sanders, eds. New Sociologies of Sex Work. Farnham: Ashgate, 91-108.

Kaun, A. 2010. “Open-ended Online Diaries: Capturing Life as it is Narrated," International Journal of Qualitative Methods, 9.2, 133-48.

Kincheloe, J. L., and P. McLaren. 2005. "Rethinking Critical Theory and Qualitative Research," in N. K. Denzin and Y. S. Lincoln, eds. Handbook of Qualitative Research. London: Sage, 30342. 
King, K. 2013. "Choosing their own Paths: Mobile Methodologies for Understanding Youth Lifestyles. In T. Duncan, S. Cohen and M. Thulemark, eds. Lifestyle Mobilities: Intersections of Travel, Leisure and Migration. London: Ashgate.

Kitzinger, J. 1994. "The Methodology of Focus Groups: The Importance of Interaction between Research Participants," Sociology of Health \& IIIness, 16.1, 103-21. http:// dx.doi.org/10.1111/1467-9566.ep11347023

Kvale, S. 1996. Interviews: An Introduction to Qualitative Research Interviewing. Thousand Oaks, CA: Sage.

Leyshon, M., and J. Bull. 2011. "The Bricolage of the Here: Young People's Narratives of Identity in the Countryside," Social and Cultural Geography, 12.2, 159-80. http:// dx.doi.org/10.1080/14649365.2011.545141

Marshall, C., and G. Rossman. 2011. Designing Qualitative Research. London: Sage.

Martinson, D. 2003. In the Presence of Audience: The Self in Diaries and Fiction. Columbus, $\mathrm{OH}$ : Ohio State University Press.

Mason, J. 2006. "Mixing Methods in a Qualitatively Driven Way," Qualitative Research, 6.1, 9-25.

McGinnis, T., A. Goodstein-Stolzenberg and E. C. Saliani. 2007. “indnpride': Online Spaces of Transnational Youth as Sites of Creative and Sophisticated Literacy and Identity Work," Linguistics and Education, 18, 283-304. http://dx.doi.org/10.1016/j.linged.2007.07.006

McKay, S., C. Thurlow and H. T. Zimmerman. 2005. "Wired Whizzes or Techno-Slaves? Young People and their Emergent Communication Technologies," in A. Williams and C. Thurlow, eds. Talking Adolescence: Perspectives on Communication in the Teenage Years. New York: Peter Lang, 185-203. 
Moinian, F. 2006. "The Construction of Identity on the Internet: Oops I've Left my Diary Open to the Whole World!" Childhood, 13.1, 49-68.

http://dx.doi.org/10.1177/0907568206058610

Monahan, T., and J. A. Fisher. 2010. "Benefits of 'Observer Effects': Lessons from the Field," Qualitative Research, 10.3, 357-76. http://dx.doi.org/10.1177/1468794110362874

Nesbitt, E. 1998. "British, Asian and Hindu: Identity, Self-Narration and the Ethnographic Interview," Journal of Beliefs and Values, 19.2, 189-200. http://dx.doi.org/10.1080/ 1361767980190203

Nesbitt, E., and E. Arweck. 2010. "Issues Arising from an Ethnographic Investigation of the Religious Identity Formation of Young People in Mixed-Faith Families," Fieldwork in Religion, $5.1,8-31$

Olson, E. 2009. “'What Kind of Catholic Are You?' Reflexivity, Religion and Activism in the Peruvian Andes," Fieldwork in Religion, 3.2, 103-21.

O'Sullivan, C. 2005. “Diaries, On-line Diaries, and the Future Loss to Archives; or, Blogs and the Blogging Bloggers who Blog them," American Archivist, 68, 53-73.

Panelli, R. 2002. "Young Rural Lives: Strategies beyond Diversity," Journal of Rural Studies, 18.2, 113-22. http://dx.doi.org/10.1016/S0743-0167(01)00047-X

Schutz, A., and T. Luckmann. 1974. The Structures of the Life-World. London: Heinemann.

Schweber, S. 2007. “Donning Wigs, Divining Feelings, and Other Dilemmas of Doing Research in Devoutly Religious Contexts," Qualitative Inquiry, 13.1, 58-84. http://dx.doi.org/10.1177/ 1077800406295483

Somers, M. R. 1994. "The Narrative Constitution of Identity: A Relational and Network Approach," Theory and Society, 23.5, 605-49. http://dx.doi.org/10.1007/BF00992905 
Valentine, G. 2000. "Exploring Children and Young People's Narratives of Identity," Geoforum, 31.2, 257-67. http://dx.doi.org/10.1016/S0016-7185(99)00047-0

Warren, J. T., and D. L. Fassett. 2002. “(Re)constituting Ethnographic Identities," Qualitative Inquiry, 8, 575-90. http://dx.doi.org/10.1177/107780002237005

Worth, N. 2009. "Making Use of Audio Diaries in Research with Young People: Examining Narrative, Participation and Audience," Sociological Research Online, 14.49, http://www.socresonline.org.uk/14/4/9.html. 